\title{
Southeast Asian
}

National Cancer Institute

\section{Source}

National Cancer Institute. Southeast Asian. NCI Thesaurus. Code C126533.

Denotes a person whose ancestry is in any of the Asian countries south of China, east of India, west of New Guinea and north of Australia. 